\title{
Kudret Narı (Momordica charantia Descourt.) Meyvesinden Saflaştırılan Peroksidaz Enzimi Kullanılarak Hibrit Nano Çiçekler Sentezlenmesi ve Direct Blue 1 Gideriminde Kullanılabilirlikleri
}

\author{
Cevahir ALTINKAYNAK ${ }^{*}$, Ayşe BALDEMIR KILIÇ², Nalan ÖZDEMIR ${ }^{3}$, Vedat \\ YILMAZ ${ }^{4}$ İ́smail ÖÇSOY ${ }^{4}$ \\ ${ }^{I}$ Nevşehir Hacı Bektaş Veli Üniversitesi, Avanos Meslek Yüksekokulu, Bitkisel ve Hayvansal Üretim Bölümü, \\ 50500, Nevşehir. \\ ${ }^{2}$ Sağlık Bilimleri Üniversitesi, Gülhane Eczacılık Fakültesi, Farmasotik Botanik Bölümü, 06018, Ankara, \\ ${ }^{3}$ Erciyes Üniversitesi, Fen Fakültesi, Kimya Bölümü, 38039, Kayseri \\ ${ }^{4}$ Erciyes Üniversitesi, Eczacılık Fakültesi, Analitik Kimya Bölümü, 38039, Kayseri \\ (ORCID: 0000-0003-0082-8521)(ORCID: 0000-0003-2473-4837) (ORCID: 0000-0002-8930-5198)
}

(ORCID: 0000-0002-1719-1638)(ORCID: 0000-0002-5991-3934)

\begin{abstract}
Öz
Farklı bitkisel kaynaklardan saflaștırılan peroksidaz enzimleri verimli bir șekilde endüstriyel atıklarda yer alan boyar maddelerin gideriminde kullanılmaktadır. Ucuz ve kolay ulaşılabilir bitkisel bir kaynak olan kudret narı (Momordica charantia) meyvesi önemli bir peroksidaz kaynağıdır. Bu nedenle çalışmada kudret narı meyvesinin ham ve olgun halinden amonyum sülfat çöktürme yöntemi ile saflaştırılan peroksidaz enzimi kullanılarak çiçek şekilli hibrit nano yapı elde edilmesi ve enzimatik aktivitelerinin karşılaştırmalı olarak ölçülerek direct blue 1 boya gideriminde kullanılabilirlikleri hedeflenmiştir. Elde edilen verilere göre ham kudret narı meyvesinden yapılan $\% 50$ oranında protein çöktürmesi sonucu toplam protein miktarı $0,485 \mathrm{mg} / \mathrm{mL}$ bulunurken peroksidaz aktivitesi $2360,9 \mathrm{EU} / \mathrm{mg}$ olarak tespit edilmiştir. Bunun yanında olgun kudret narı meyvesinden yapılan $\% 60$ oranında protein çöktürmesi sonucu ise toplam protein miktarı $0,232 \mathrm{mg} / \mathrm{mL}$ iken serbest peroksidaz aktivitesi 7719,30 EU/mg olarak tespit edilmiştir. Farklı büyüme safhalarında yer alan meyvelerden optimum koşullarda saflaştırılmış peroksidaz enzimleri enzim-inorganik hibrit nano çiçek sentez yöntemi ile immobilize edildiğinde serbest formlarına göre daha yüksek enzimatik aktivite sergilemişlerdir. En yüksek peroksidaz aktivitesi olgun meyvede ve hibrit nano çiçek formunda (19661,6 EU/mg) görülmüştür. Ayrıca çalışmada tekstil endüstrisinde yaygın olarak kullanılan Direct Blue 1 boyasının giderimi için hibrit nano çiçeklerin serbest peroksidaz enzimleri ile karşılaştırmalı olarak kullanılabilirlikleri araştırılmıştır. Özellikle ham meyve peroksidazı kullanılarak sentezlenen hibrit nano çiçek formunun daha fazla boya giderimi yaptığı tespit edilmiştir.
\end{abstract}

Anahtar kelimeler: Kudret Narı Peroksidaz, Hibrit Nano Çiçek, Boya Giderimi.

\section{Synthesis of Hybrid Nanoflowers Using The Purified Bitter Gourd (Momordica charantia Descourt.) Peroxidase and its Usability Of Direct Blue 1 Decolorization}

\begin{abstract}
Peroxidase enzymes are purified from different plant sources are used efficiently for the removal of dyes in industrial wastes. The fruit of bitter gourd (Momordica charantia), an inexpensive and easily accessible vegetable, is an important source of peroxidase. For this reason, the aim of this study was to investigate hybrid nanoflower by using purified peroxidase enzyme from green and ripe form of bitter gourd via ammonium sulphate precipitation method, and to compare their enzymatic activities by direct blue 1 dye removal. According to the data, total protein content was found to be $0.485 \mathrm{mg} / \mathrm{mL}$ and peroxidase activity was found to be $2360.9 \mathrm{EU} / \mathrm{mg}$ as a result of $50 \%$ protein precipitation made from green bitter gourd. However; total protein amount was $0.232 \mathrm{mg} / \mathrm{mL}$ and free
\end{abstract}

*Sorumlu yazar: caltinkaynak@nevsehir.edu.tr Geliș Tarihi: 07.08.2019, Kabul Tarihi: 20.03.2020 
peroxidase activity was determined as $7719.30 \mathrm{EU} / \mathrm{mg}$ as a result of $60 \%$ protein precipitation made from ripe bitter gourd. Peroxidase enzymes which were purified from bitter gourd in different growth stages under optimum conditions showed higher enzymatic activity compared to free forms when immobilized via enzyme-inorganic hybrid nanoflower synthesis method. The highest peroxidase activity was seen in mature fruit and hybrid nanoflower form (19661, $6 \mathrm{EU} / \mathrm{mg}$ ). In addition, the usability of hybrid nanoflowers was investigated compared to the free purified peroxidase for removal of Direct Blue 1 dye widely used in textile industry. It was determined that hybrid nanoflower form synthesized especially by using ripe bitter gourd peroxidase had more dye removal.

Keywords: Bitter Gourd Peroxidase, Hybrid Nanoflower, Decolorization

\section{Giriş}

Son yıllarda araştırmacılar fenolik kirleticilerin atık sulardan uzaklaştırılmasına yönelik klasik kimyasal arıtma yöntemlerine alternatif kullanılabilecek mikrobiyal uygulamaların kullanımına odaklanmışlardır [1-5]. Peroksidazlar ve polifenol oksidazlar gibi oksidoredüktif enzimler, aromatik kirletici maddelerin giderilmesinde çok önemli bir rol oynamaktadır. Bu enzimler substratlara etki ederek, ortamdaki çok düşük konsantrasyonlarda organik kirleticilerin uzaklaştırılmasını katalize etmektedirler. Boyalardan fenolik bileşenlerin giderilmesi sürecinde bazı mikrobiyal, bitkisel ve polifenol oksidaz türler görev almaktadır. Ancak bu süreç fazla maliyetli olduğundan dolayı dezavantajlı görünmektedir $[6,7]$.

Özellikle endüstriyel biyokatalizörler olarak enzimlerin pratikte kullanılabilmeleri için etkinliklerinin, aktivitelerinin, kararlılıklarının ve geri kazanımlarının arttırılması gerekmektedir [8]. Bu amaçla enzim immobilizasyonu son yıllarda yoğun olarak çalışılmaktadır. İmmobilizasyon, enzimlerin katı bir destek üzerine tutturulması ya da içerisine hapsedilmesi şeklinde gerçekleştirilebilir. Enzim immobilizasyonunda kovalent bağlama, çapraz bağlama, adsorpsiyon, tutuklama ve enkapsüle etme şeklinde beş farklı yaklaşım vardır [9]. İmmobilizasyon işlemi ile enzim kararlılığındaki artış enzimin ekonomik olarak sonraki pratik uygulamalarda kullanılmasını mümkün kılmaktadır [10]. Ancak konvansiyonel immobilizasyon çalışmalarında immobilize edilen enzimlerin serbest enzime göre kararlılıklarının artmasına rağmen aktivitelerinin düştüğü görülmüştür [1,11]. Son yıllarda, farklı bir enzim immobilizasyon yaklaşımı kullanılarak enzimlerin aktivitesinin ve kararlılığının yükseltilmesi hedeflenmektedir. Bu amaçla bazı protein/enzim ve metal iyonlarının fosfat tampon içerisinde inkübasyonu ile çiçek şekilli hibrit yapıların sentezi literatürde rapor edilmiştir [11,12]. Rapor edilen bu çalışmalarda, sentezlenen hibrit nano çiçek formundaki enzimlerin aktivitesinin ve kararlılığının serbest enzimlere göre dikkat çekici ölçüde arttı̆̆ gösterilmiştir [11-16].

Son yıllarda, peroksidaz çalışmaları, klinik, endüstriyel ve çevresel alanlar gibi geniş spektrumlu uygulamaları nedeniyle giderek artmaktadır. Özellikle, peroksidazların fenolik kirleticileri kirli atık sulardan uzaklaştırmak için etkili bir şekilde kullanılabildiği birçok çalışma ile kanıtlanmıştır [6,17]. Peroksidazlar, doğada (hayvanlar, bitkiler ve mikroorganizmalarda) yaygın olarak bulunan ve hidrojen atomlarını verme eğiliminde olan bileşikler ile bu atomları alıcı durumunda olan $\mathrm{H}_{2} \mathrm{O}_{2}$ bileşiği arasındaki reaksiyonu katalizleyen oksidoredüktaz sınıfı enzimlerdir [18]. Bu grup enzimler, hidrojen peroksiti kullanarak organik ve inorganik substratların oksidasyonunu, fenoller, hidrokinonlar, hidrokinonid aminler gibi çok sayıda aromatik bileşiklerin dehidrogenasyonu reaksiyonlarını katalizler [17, 19]. Peroksidaz enziminin sayılan bu özellikleri enzimi mikroanalitik, biyomedikal ve endüstriyel uygulamalarda kullanışlı hale getirmektedir. Endüstriyel boyutta peroksidaz enzimi saflaştırılması için yeni kaynaklar devamlı araştırılmaktadır.

Bitkisel peroksidaz enzimleri 200 den fazla çok çeşitli kaynaktan saflaştırılmaktadır ve Momordica charantia (kudret narı) meyvesi önemli bir peroksidaz kaynağı olarak karşımıza çıkmaktadır. Meyve siğile benzer diş ve yoğun çıkıntılı uzun şekillidir. Yeşil renkli ham meyve sebze olarak tüketilebilirken sarı-turuncu renkli olgunlaşmış hali çeşni olarak kullanılmaktadır [20]. Yapılan klinik çalışmalar ile kudret narı meyve, tohum ve yapraklarından elde edilen ekstrelerin biyoaktif bileşenler içerdiği, anti-fungal, anti-inflamatuar, ateş düşürücü veya yara iyileştirici olarak tedavi edici fonksiyon gösterdiği kanıtlanmıştır [21]. Bitki; saponinler, polisakkaritler, proteinler, triterpenler, alkaloitler, flavonoitler, kinin, aminoasitler, yağ asitleri (\%7.5-20 palmitik asit, \%0.3-3.5 palmitoleik asit, \%0.5-5 stearik asit, \%55-83 oleik asit, \%3.5-21 linoleik asit, <\%1.0 linolenik asit) ve eser elementler gibi farklı türde bileşenler içerir [20].

$\mathrm{Bu}$ çalışmada; daha ucuz ve kolay ulaşılabilir bitkisel bir kaynak olan kudret narı meyvesinin ham ve olgun halinden amonyum sülfat çöktürme yöntemi ile peroksidaz enzimini yüksek verimlilikle 
saflaştırmak, elde edilen enzimler kullanılarak yeni bir immobilizasyon yöntemi olan çiçek şekilli hibrit nano yap1 formuna dönüştürdükten sonra enzimatik aktivitelerini karşılaştırmalı olarak araştırmak ardından, direct blue 1 boya gideriminde kullanılabilirlikleri belirlenmesi araştırılmıştır.

\section{Materyal ve Metod}

\subsection{Kimyasallar ve Materyaller}

At turpu peroksidaz (Cat.No.77332), Bovine serum albumin (BSA), hidrojen peroksit $\left(\mathrm{H}_{2} \mathrm{O}_{2}\right)$, guaicol, bakır sülfat penta hidrat, sodyum asetat, amonyum sülfat, methanol, fosforik asit, ve diğer kimyasallar Sigma-Aldrich'den satın alındı. Direct blue 1 boyası ise Alfa Aesar (A14242) den satın alındı. NaCl, $\mathrm{KCl}, \mathrm{Na}_{2} \mathrm{HPO}_{4}, \mathrm{KH}_{2} \mathrm{PO}_{4}, \mathrm{HCl}, \mathrm{NaOH}$ and Coomassie brilliant blue $\mathrm{G}-250$ kimyasalları çözeltilerin hazırlanmasında kullanıldı. SnakeSkin ${ }^{\mathrm{TM}}$ Dialysis Tubing, 10K MWCO, (Thermo 68100) ise diyaliz aşamasında kullanıldı.

\subsection{Kudret narı proteinlerinin amonyum sülfat saflaştırması}

Ham ve olgun $M$. charantia meyvesi Erciyes Üniversitesi Seyrani Ziraat Fakültesi kültür koleksiyonlarından temin edildi. $10 \mathrm{~g}$ kudret narı $20 \mathrm{~mL} 0.1 \mathrm{M}$ sodyum asetat (pH 5.6) solüsyonu ile homojenize edildi. Elde edilen ham homojenat Akhtar ve arkadaşlarının tanımladığı yönteme göre hazırlandı [21]. Homojenat, dört kat tülbentten süzüldü. Süzüntü daha sonra $10.000 \mathrm{~g},+4^{\circ} \mathrm{C}$ de $15 \mathrm{dk}$ santrifüj edildi. Elde edilen berrak süpernatanta, $\%$ 50-80 (w/v) $\left(\mathrm{NH}_{4}\right)_{2} \mathrm{~S}_{4}$ ilave edilerek fraksiyonlarına ayrıldı. Maksimum çökelti elde etmek için fraksiyonlar $+4^{\circ} \mathrm{C}^{\prime}$ de gece boyunca karıştırıldı. Pellet, 10.000 $\mathrm{g},+4^{\circ} \mathrm{C}^{\prime} \mathrm{de} 15 \mathrm{dk}$ santrifüj sonrası toplandı. Elde edilen pellet uygun miktarda deiyonize su içinde yeniden çözüldü ve pH 7.4 fosfat tamponuna karşı diyaliz edildi. Protein konsantrasyonu, standart olarak BSA kullanılarak Bradford protein tahlil yöntemi ile ölçüldü.

\subsection{Hibrit nano çiçeklerin hazırlanması ve karakterizasyonu}

Hibrit nano çiçekler Zare ve arkadaşlarının tanımladığı yönteme göre sentezlendi [12]. İlk olarak; ham ve olgunlaşmış $M$. charantia meyvesinden saflaştırılmış peroksidaz enzimi $\left(0.02 \mathrm{mg} \mathrm{mL}^{-1}\right) \mathrm{ve} \mathrm{Cu}^{+2}(0.8$ $\mathrm{mM}$ ) fosfat tampon ( $\mathrm{pH}$ 7.4) içerisinde çözüldü. Karışım $30 \mathrm{~s}$ vortexlendikten sonra 3 gün boyunca $+4^{\circ} \mathrm{C}^{\prime}$ de inkübasyona bırakıldı. İnkübasyon sonrası oluşan mavi renkli pellet santrifüj ile toplandı ve bağlanmayan protein ve metal iyonlarının ortamdan uzaklaştırılması için 3 defa saf su ile yıkama yapıldı. Sentez sonrası süpernatanta enkapsülasyon verimi hesaplanabilmesi için protein tayini yapıldı. Ardından pellet oda sicaklığında vakum altında kurutuldu. Hibrit nano çiçeklerin morfolojisi elektron mikroskobu (SEM) ile görüntülendi. Elementel kompozisyonları Enerji-dağılımlı X-Ray tekniği (EDX) ile karakterize edildi. Kimyasal yapısı ise Fourier Dönüşümü Kızılötesi Spektroskopisi (FTIR) ile analiz edildi.

\subsection{Peroksidaz enzim aktivitesi ölçümü}

Peroksidaz enzim aktivitesi, PBS ( $\mathrm{pH}$ 6.8) tamponunda substrat olarak guaiacol kullanılarak kolorimetrik ve spektroskopik yöntemler kullanılarak belirlendi. Aynı miktarda hibrit nano çiçekler ve serbest peroksidaz enzimi, $1 \mathrm{~mL}$ PBS'de (pH 6.8) ayrı ayrı çözüldü ve daha sonra her reaksiyon tüpüne $1 \mathrm{~mL} 22.5 \mathrm{mM} \mathrm{H}_{2} \mathrm{O}_{2}$ ve $1 \mathrm{~mL} 45 \mathrm{mM}$ guaiacol ilave edildi. $470 \mathrm{~nm}$ 'de spektrometrik absorbans, UV-Vis spektrofotometresi (HIT ACHI UH5300) kullanılarak ölçüldü.

\subsection{Direct blue 1 boya giderimi deneyleri}

Suda hazırlanmış $1 \mathrm{mg} \mathrm{mL}^{-1}$ stok boya çözeltisi oda sıcaklığında karanlıkta saklandı. $1.85 \mathrm{~mL}$ PBS (pH 5-6-7-8-9-10), $150 \mu 1$ stok boya çözeltisi $(50 \mathrm{mg} / \mathrm{L})$ ve $1 \mathrm{~mL} \mathrm{H}_{2} \mathrm{O}_{2}(22,5 \mathrm{mM})$ nihai hacim $3 \mathrm{~mL}$ olacak şekilde reaksiyon tüpüne ilave edildi. Reaksiyon karışımı kuvvetlice karıştırıldı. Ardından her bir tüpe aynı miktarda hibrit nano çiçek ve peroksidaz $\left(0,25 \mathrm{mg} \mathrm{mL}^{-1}\right)$ enzimi ilave edildi. Reaksiyon tüpleri farklı sicaklıklarda $\left(25^{\circ} \mathrm{C}, 40^{\circ} \mathrm{C}\right.$ ve $\left.60^{\circ} \mathrm{C}\right)$, çalkalamadan ve tamamen karanlıkta inkübe edildi. Daha 
sonra hibrit nano çiçekler santrifüj ile ortamdan ayrıldı. Kalan boya konsantrasyonu 618 nm'de spektrofotometrik olarak ölçüldü ve aşağıdaki formül ile boya giderimi hesaplandı.

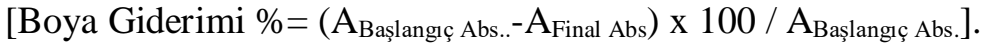

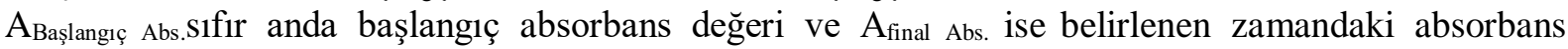
değeridir.

\subsection{Direct blue 1 boya gideriminde hibrit nano çiçeklerin tekrar kullanılabilirliği}

Direct blue 1 boya gideriminde hibrit nano çiçeklerin tekrar kullanılabilirlik çalışması yapıldı. Deney periyodu sonras1, reaksiyon çözeltisi $5000 \mathrm{rpm}$ 'de santrifüjlendi ve pellet ilgisiz molekülleri uzaklaştırmak için $3 \mathrm{kez}$ saf su ile yıkandı. Yıkanan hibrit nano çiçekler, bölüm 2.5'te belirtildiği gibi aynı prosedürde tekrar kullanıldı.

\section{Bulgular ve Tartışma}

\subsection{Kudret narı proteinlerinin amonyum sülfat saflaştırması}

Ham ve olgunlaşmış kudret narı meyvesinden toplam protein saflaştırması \%50-80 aralı̆̆ında amonyum sülfat tuzu kullanılarak protein çöktürmesi yapılırken eş zamanlı olarak en yüksek peroksidaz aktivitesi gösteren koşul da tespit edildi. Ham kudret narı meyvesinden elde edilen peroksidaz enzimi GP olarak kodlanırken, olgun kudret narı meyvesinden elde edilen peroksidaz enzimi RP olarak kodlandı.

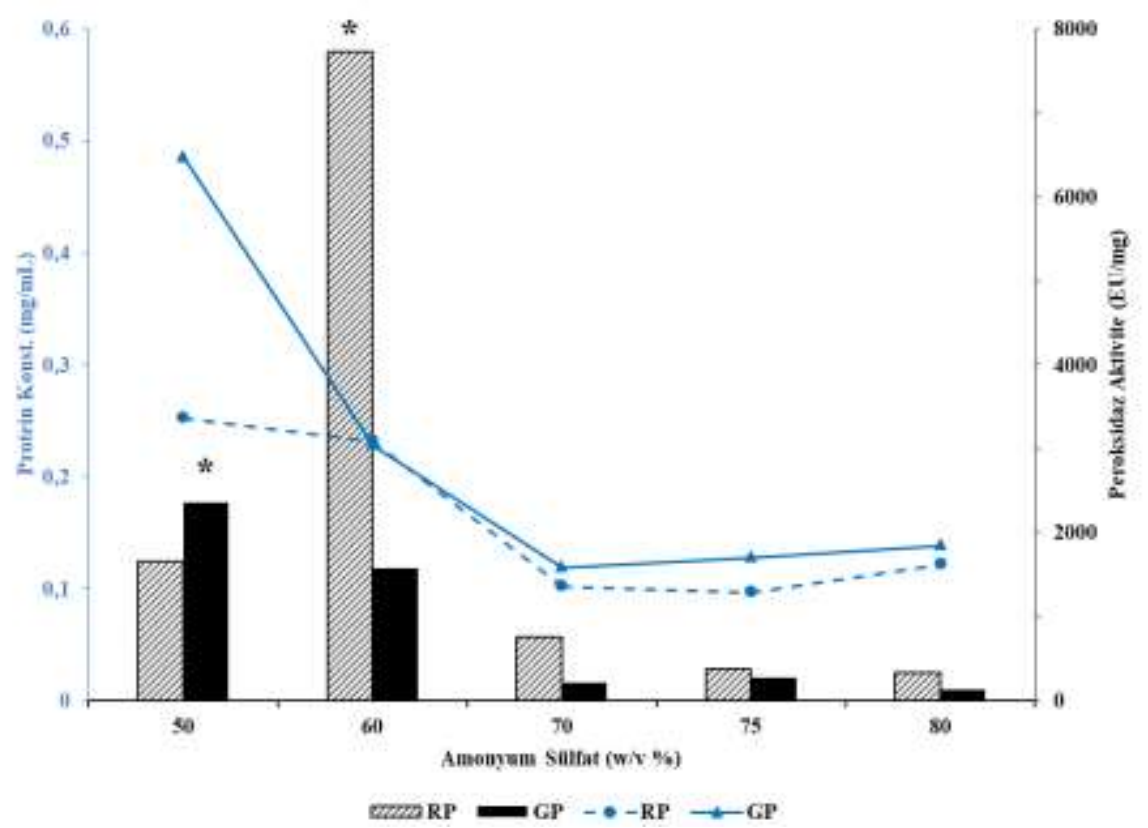

Şekil 1. Ham ve olgunlaşmış kudret narı meyve proteinlerinin amonyum sülfat saflaştırması üzerine etkisi (İşaretlenmiş kolonlar (*) optimum koşul olarak tespit edilmiştir).

Şekil 1'de görüldüğü üzere RP için \%60, GP için \%50 oranında amonyum sülfat çöktürmesi optimum koşul olarak tespit edildi ve peroksidaz enzimi bu koşullarda gece boyu bekletilerek çökmenin tam olması sağlandı. RP, en yüksek peroksidaz aktivitesinin $(7719,30 \mathrm{EU} / \mathrm{mg})$ olduğu \%60 oranında, protein miktarı $0,232 \mathrm{mg} \mathrm{mL}^{-1}$ iken GP için peroksidaz aktivitesinin $(2360,9 \mathrm{EU} / \mathrm{mg})$ en yüksek olduğu çöktürme koşulu \%50 olarak görülmüştür. Bu oranda yapılan protein tayin sonucu ise $0,485 \mathrm{mg} \mathrm{mL}^{-1}$ dır. En düşük protein konsantrasyonu \%70 oranında amonyum sülfat çöktürmesi sonucu elde edilmiştir. Dhanashree ve arkadaşları $M$. charantia meyvesiden peroksidaz enzimi saflaştırmasında amonyum sülfat tuzunun maksimum enzim kazanımına neden olduğunu ifade ederek yöntemimizi desteklemektedir [23]. Olgun meyveden yapılan enzim saflaştırması ham meyveden yapılan enzim saflaştırmasına göre daha yüksek peroksidaz enzim aktivitesi göstermektedir. Benzer şekilde, Akthar ve 
arkadaşları yaptıkları çalışmada kudret narı proteinlerinin amonyum sülfat çöktürmesi ile fraksiyonlarına ayrıldığında çok yüksek peroksidaz aktivitesi sergilediğini rapor etmişlerdir [22]. Kudret narı meyvesinden saflaştırılmış peroksidaz enzimi göre son derece ucuz ve kolaylıkla ulaşılabilir bir kaynak olup ticari enzimlere alternatiftir [22].

\subsection{Hibrit nano çiçeklerin hazırlanması ve karakterizasyonu}

Hibrit nano çiçek yapıların sentezinde organik bileşen olarak ham ve olgun meyveden saflaştırılmış peroksidaz enzimi ve inorganik bileşen olarak $\mathrm{Cu}^{2+}$ iyonları kullanıldı. Bu yöntem de çiçek şekilli nano yapılar, fosfat tamponu ile $\mathrm{Cu}^{2+}$ nin oluşturduğu yapıyla proteinlerin kompleks oluşturması esasına dayanır [24,25]. Oluşum mekanizmasında ilk olarak birincil bakır fosfat kristalleri oluşur. Bu aşamada protein molekülleri baskın olarak $\mathrm{Cu}$ (II) iyonları ile özellikle protein omurgasındaki amin gruplarının koordinasyonu sayesinde kompleksler oluştururlar. Oluşan bu kompleksler bakır fosfat birincil kristallerin çekirdeklenme alanları haline gelir. İkincil büyüme aşamasında, protein molekülleri ve primer kristaller iri topaklar haline gelir. Bakır fosfat kristallerinin kinetik olarak kontrolü agregatların yüzeyindeki bireysel bakır bağlayıcı bölgelerden kaynaklanır bu da ayrı ayrı yaprakların oluşmasına neden olur. Son aşamada anizotropik büyüme dallı ve çiçek şekilli hibrit nano yapının oluşması ile sonuçlanır. Bu büyüme sürecinde, protein yaprak skafoldların oluşturulması için bakır fosfat kristalleri çekirdeklenmeyi indükler ve yaprakları birbirine bağlamak için bir "tutkal" olarak görev yapar. Nano boyuttaki bu yaprak şekilli yapılar bir araya gelerek birbirine bağlanırlar ve mikro boyutlu hibrit nano çiçekleri oluştururlar. Bu nedenle sentezlenen yapılar "hibrit nano çiçek-nanoflower (nfs)" olarak yöntemi keşfeden Zare ve ekibi tarafından adlandırılmıştır [12].

Olgun ve ham meyveden başarıyla saflaştırılmış peroksidaz enzimlerinden hibrit nano çiçek standart protokol ile elde edildi [12,23,24]. Ham ve olgun kudret narı meyvesinden optimum koşullarda saflaştırılmış peroksidaz enzimi $0.02 \mathrm{mg} \mathrm{mL}^{-1}$ konsantrasyonda PBS (pH 7.4) tamponunda hibrit nano çiçek eldesi için kullanılmıştır. Şekil 2'de sentezlenen hibrit nano çiçek yapıların elektron mikroskop görüntüleri verilmiştir. Şekil 2 (A,B,C) olgun meyve peroksidazı kullanılarak sentezlenmiş hibrit nano çiçeğin morfolojisini aydınlatmaktadır, bu yapı RPnfs olarak kodlanmıştır. Şekil 2 (D,E,F) ise ham meyve peroksidazı kullanılarak sentezlenmiş hibrit nano çiçeğin morfolojisini aydınlatmaktadır, bu yapı ise GPnfs olarak kodlanmıştır. Şekil 2'de görüldüğü üzere büyük yapraklar küre şeklinde çiçek benzeri morfolojiye sahip olup sıkı şekilde paketlenmiştir. RPnfs yaklaşık $4 \mu \mathrm{m}$ boyutunda iken GPnfs yaklaşık $10 \mu \mathrm{m}$ boyutunda hibrit yapı oluşturmuş̧tur. Her iki sentez sonucu homojen bir morfoloji söz konusudur.
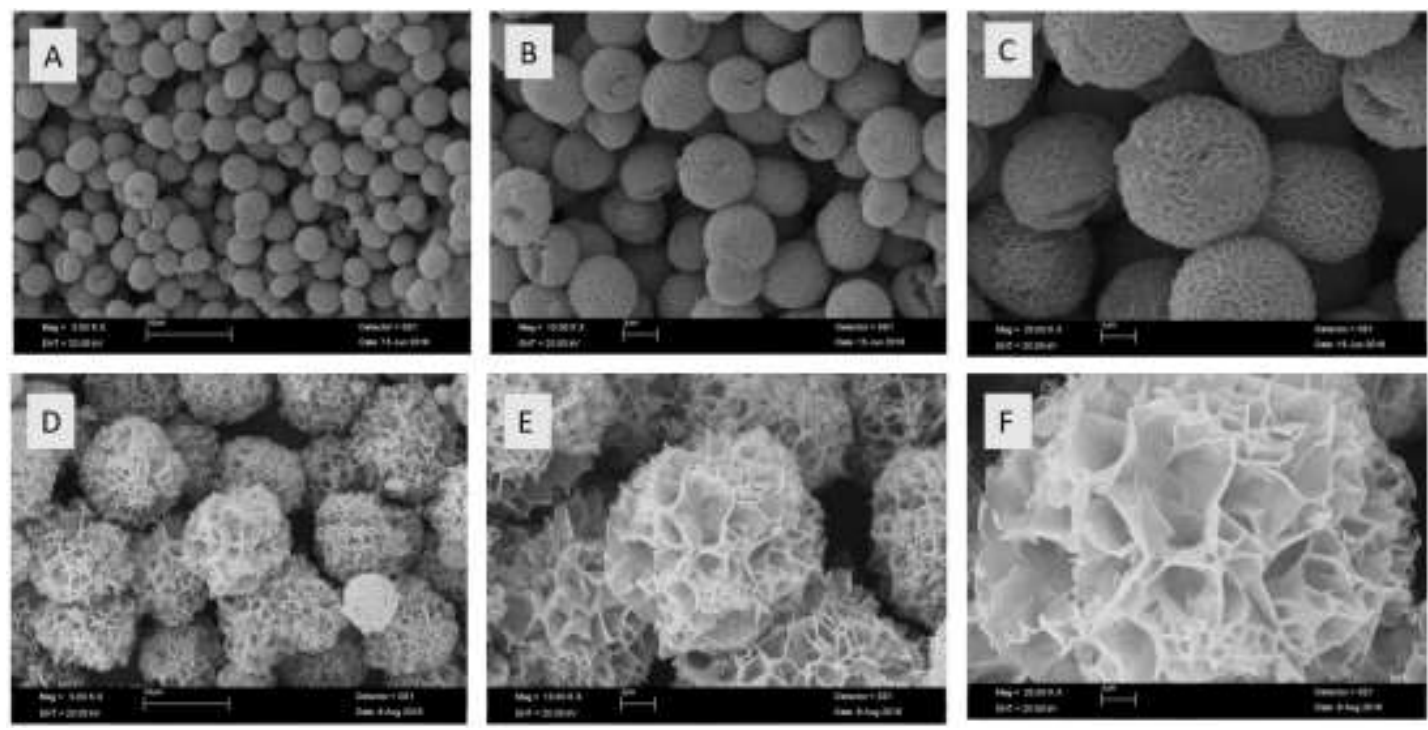

Şekil 2. Saflaştırılan peroksidaz enzimi $\left(0.02 \mathrm{mg} \mathrm{mL}^{-1}\right)$ ile sentezlenen hibrit nano çiçeklerin elektron mikroskop görüntüsü; (A, B, C) RPnfs; (D, E, F) GPnfs. 


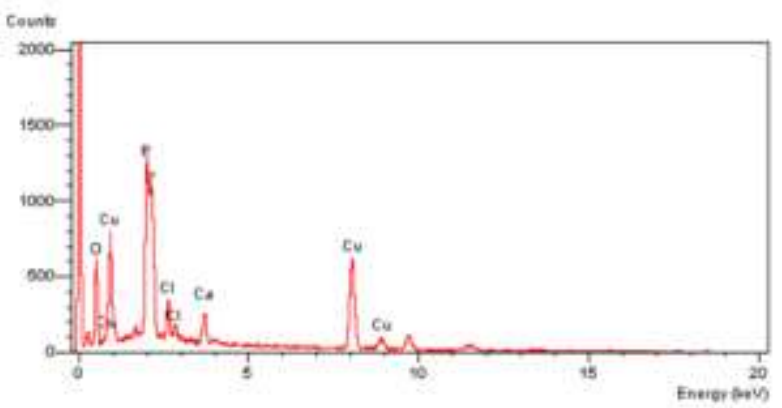

(a)

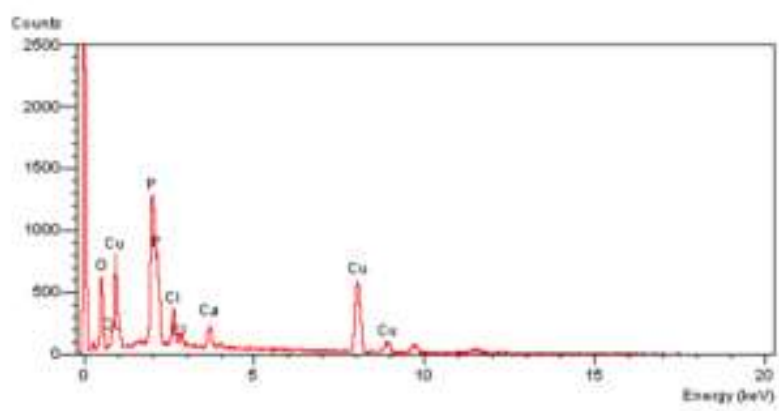

(b)

Şekil 3. Sentezlenen (a) RPnfs (b) GPnfs hibrit nano çiçeklerin EDX spektrumu

Sentezlenen hibrit nano çiçek yapıların elementel içeriği EDX tekniği ile analiz edilmiştir. Şekil 3'de her iki hibrit nano çiçek yapıda var olan Cu metaline karşılık gelen pikler açıcça görülmektedir.

Saflaştırılmış serbest peroksidaz enzimi ve hibrit nano çiçek yapıları hakkında bilgi sahibi olmak ve enzim immobilize edildiğinde serbest yapıda meydana gelen değişiklikleri incelemek için FTIR spektrum analizi yapıldı. Serbest peroksidaz enziminin karakteristik pikleri Şekil 4 (A ve C)' de verilen FTIR spektrumunda gösterilmiştir. Şekil 4'de $\sim 578$ ve $624 \mathrm{~cm}^{-1}$ 'de gözlenen P-O grubu frekansları immobilize edilmiş yapıda $\sim 620 \mathrm{~cm}^{-1}$, deki frekanslara kayma göstermiştir. $\sim 1100 \mathrm{~cm}^{-1}$, deki bantlar $\mathrm{P}=\mathrm{O}$ grubuna spesifiktir ve hibrit nano çiçek yapısında $\sim 960 \mathrm{~cm}^{-1}, 1042 \mathrm{~cm}^{-1}$ ve $1153 \mathrm{~cm}^{-1}$ frekanslarına kayma göstermiştir. Serbest peroksidaz enzimindeki -CONH grubuna ait olan bant frekansi $\sim 1635 \mathrm{~cm}^{-1}$ iken [26] hibrit nano çiçek yapısında bant kayma göstererek $\sim 1620 \mathrm{~cm}^{-1}$ de görünmektedir. 2100-3400 $\mathrm{cm}^{-1}$ aralığındaki bantlar ise $-\mathrm{CH}_{2}$ ve $-\mathrm{CH}_{3}$ gruplarına aittir ve serbest peroksidaz enziminde şiddetli iken hibrit nano çiçek yapısında daha zayıf olarak görülmüştür.
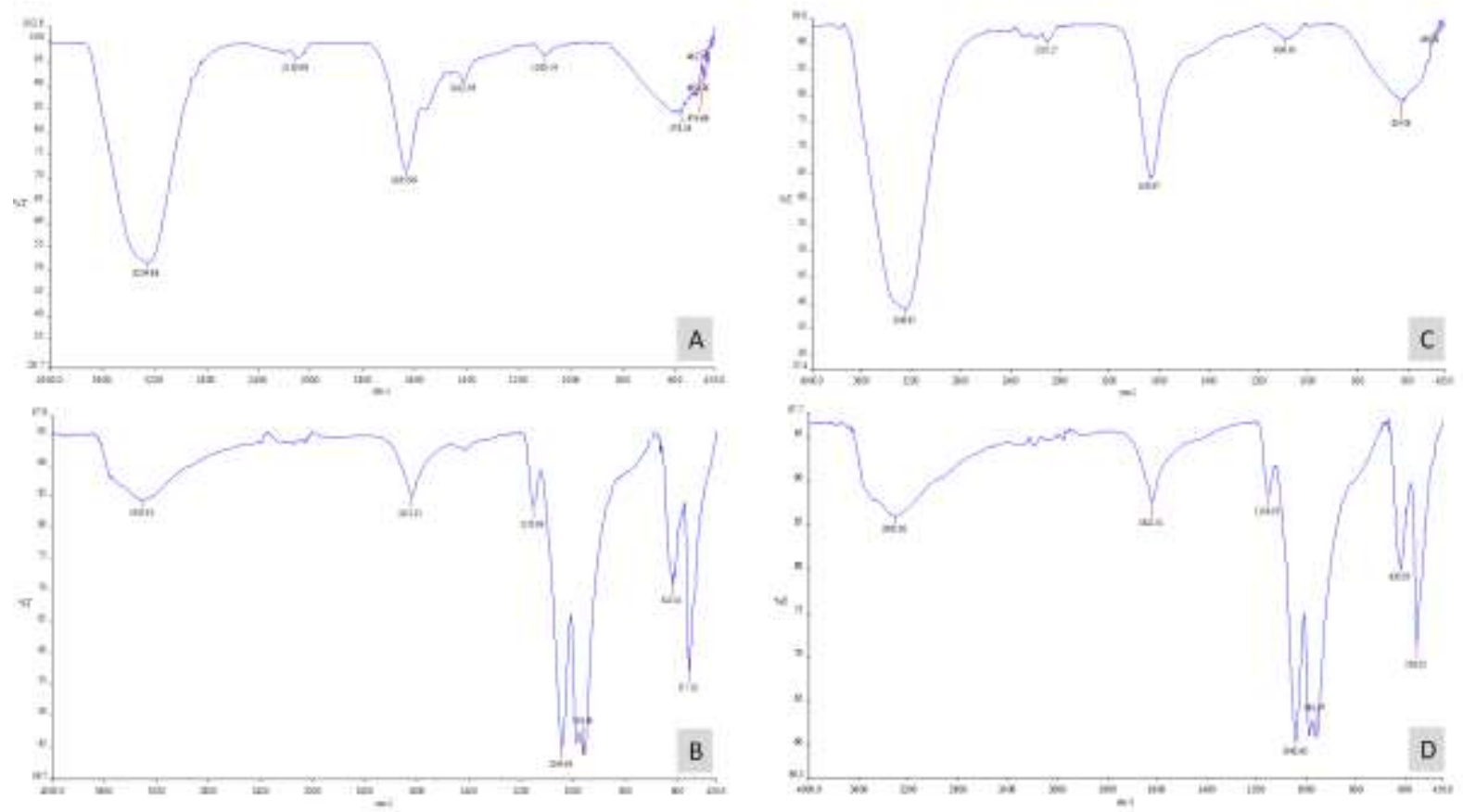

Şekil 4. (A) Serbest RP (B) RPnfs (C) Serbest GP ve (D) GPnfs yapılarının FTIR spektrumları

\subsection{Hibrit nano çiçeklerin enzimatik aktivitesi}

Olgun ve ham meyveden \%50-60-70-75-80 konsantrasyonda amonyum sülfat tuzu kullanılarak çöktürülen peroksidaz enzimlerinden hibrit nano çiçek elde edildi ve serbest formları ile peroksidaz aktivite karşılaştırması yapıldı (Tablo 1). Momordica charantia meyvesinde peroksidaz enzim aktivitesini ilk defa Akhtar ve arkadaşları yaptıkları çalışmada $300 \mathrm{EU} / \mathrm{mg}$ olacak şekilde tespit etmişlerdir [27]. Bu çalı̧̧mada ise olgun meyveden \%60 oranında amonyum sülfat çöktürmesi ile 
yapılan saflaştırma sonucu elde edilen serbest peroksidaz enzimi 50.dakika sonunda 7719,301 EU/mg aktivite gösterirken hibrit nano çiçek formuna dönüştürüldükten sonra aktivite 2,5 kat daha artarak 19661,660 EU/mg'a yükselmiştir. Ham meyveden yapılan saflaştırma oranlarına göre en yüksek peroksidaz aktivitesi $\% 50$ amonyum sülfat çöktürmesinde görülürken aktivite değeri 50. dakika sonunda 2360,903 EU/mg'dir. Bu enzim hibrit nano çiçek formuna dönüştürüldüğünde ise aktivite 1,76 kat artarak 4151,988 EU/mg a ulaşmıştır. Buna göre olgun meyve içerisinde biyolojik olarak aktif peroksidaz enzim miktarı daha fazladır. Çiçek şekilli hibrit nano yapıların sentezi ile serbest formda var olan aktivite artmaktadır. Konvansiyonel enzim immobilizasyon yöntemleri ile karşılaştırıldı̆̆ında hareketsiz forma dönüştürülmüş olan bir enzimin aktivitesinde artış meydana gelmesi kullanılan bu yöntemi avantajlı kılmaktadır.

Tablo 1. Ham ve olgun $M$. charantia meyvesinden saflaştırılmış serbest peroksidaz enzimleri ve hibrit nano çiçek formunun peroksidaz aktivitesi [T:50 min]

\begin{tabular}{ccccc}
\hline $\begin{array}{c}\text { Amonyum Sülfat } \\
\text { (w/v \%) }\end{array}$ & RP & RPnfs & GP & GPnfs \\
$\mathbf{5 0}$ & 1661,655 & 3581,956 & 2360,903 & 4151,988 \\
$\mathbf{6 0}$ & 7719,301 & 19661,660 & 1578,948 & 1840,602 \\
$\mathbf{7 0}$ & 757,895 & 4547,370 & 215,489 & 270,677 \\
$\mathbf{7 5}$ & 375,940 & 1052,633 & 270,124 & 383,459 \\
$\mathbf{8 0}$ & 330,827 & 1060,152 & 135,338 & 351,880 \\
\hline
\end{tabular}

Olgun ve ham meyveden optimum koşullarda peroksidaz enzimi saflaştırılıp hibrit nano çiçek haline dönüştürüldükten sonra serbest form ile karşılaştırmalı olarak 50 dakikalık bir aktivite kontrolü sağlandı (Şekil 5). Serbest enzimleri ile yapılan karşılaştırmada en yüksek aktivite olgun meyvede ve hibrit nano çiçek formunda görüldü.

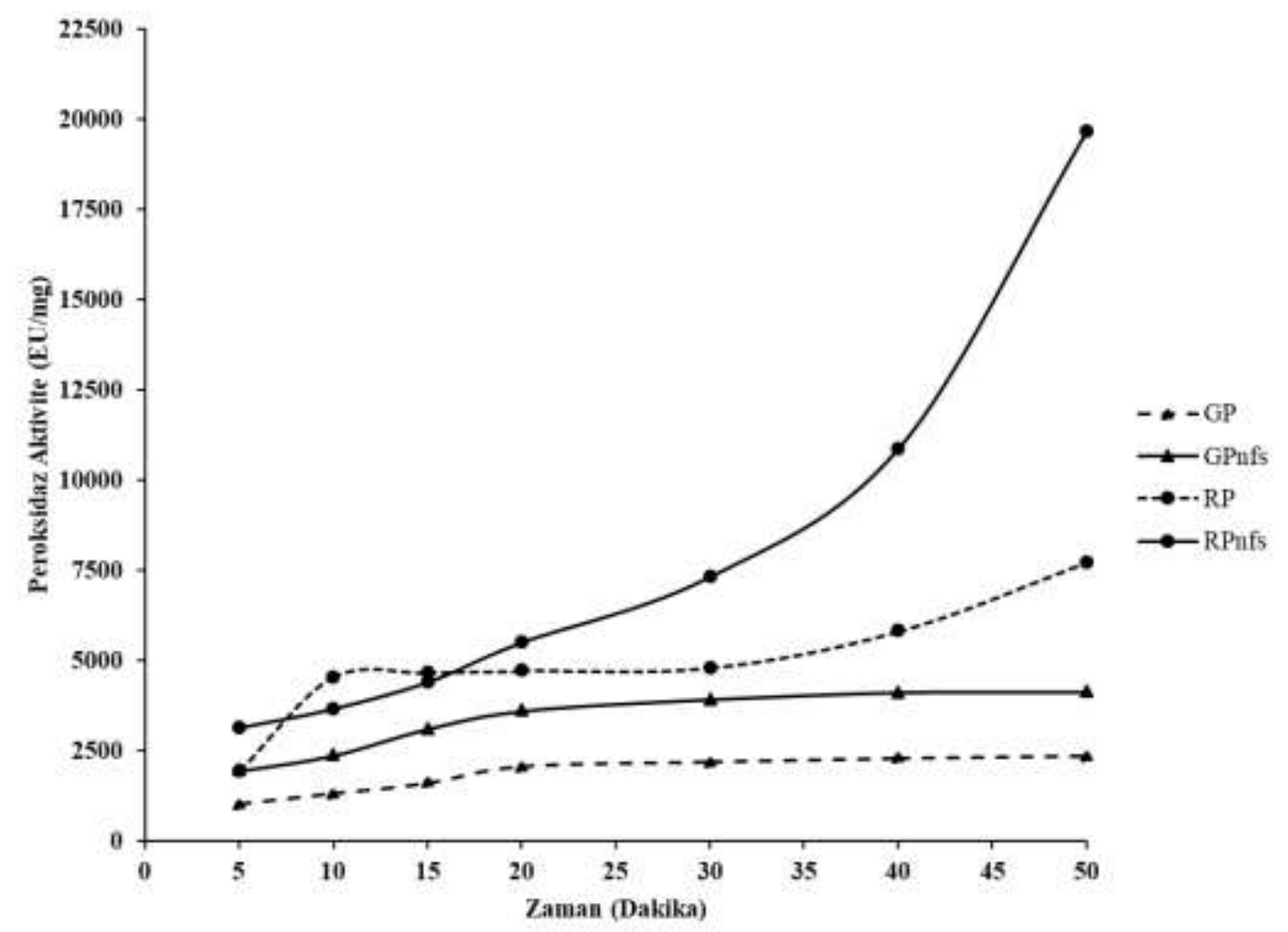

Şekil 5. Peroksidaz enzim aktivitesine zamanın etkisi 


\subsection{Direct blue 1 enzimatik boya giderimine pH'nın etkisi}

Endüstriyel olarak Direct blue 1 olarak tanımlanan boya Chicago sky blue olarak da bilinmektedir. Azo grubu boyalardan olup son derece kanserojendir. Maksimum absorbsiyon gösterdiği dalga boyu $\lambda \max =618$ nm' dir. Hibrit nano çiçek yapıların Direct blue 1 gideriminde optimum $\mathrm{pH}$ koşulunun tespit edilebilmesi için $\mathrm{pH}$ 5-10 aralığında PBS tamponları kullanılarak $50 \mathrm{mg} / \mathrm{L}$ konsantrasyonda boya giderimi 50.dak ve $25^{\circ} \mathrm{C}$ ayrı ayrı gerçekleştirildi. Farklı $\mathrm{pH}$ değerlerine sahip tampon ortamında yapılan giderim sonrası Şekil 6'da görüldüğü üzere optimum pH değeri hem RPnfs hemde GPnfs için pH 9 olarak tespit edilmiştir. 50. dakikada RPnfs için boya giderimi \%100 iken GPnfs için \%76 olarak belirlenmiştir. Daha önce Akhtar ve arkadaşları tarafından kudret narı meyvesinden peroksidaz enzimi saflaştırması yapılmış ve saflaştırılan enzim Con A-Sephadex üzerine immobilize edilerek 50-200 mg/L konsantrasyonda yer alan çeşitli boya giderimlerinde kullanılmıştır [28]. Amcak Akhtar bu çalışmasında direct blue boya giderimini test etmemiş olup Reactive Blue 4-160-171, Reactive Orange 4-86, Reactive Red 120 ve Reactive Yellow 84 gibi boyalar için optimum çalışma koşulunu pH 3.0-4.0 aralı̆̆ olarak belirlemiş olup boya giderimini \%80-98 aralığında gözlemlemiştir [28].

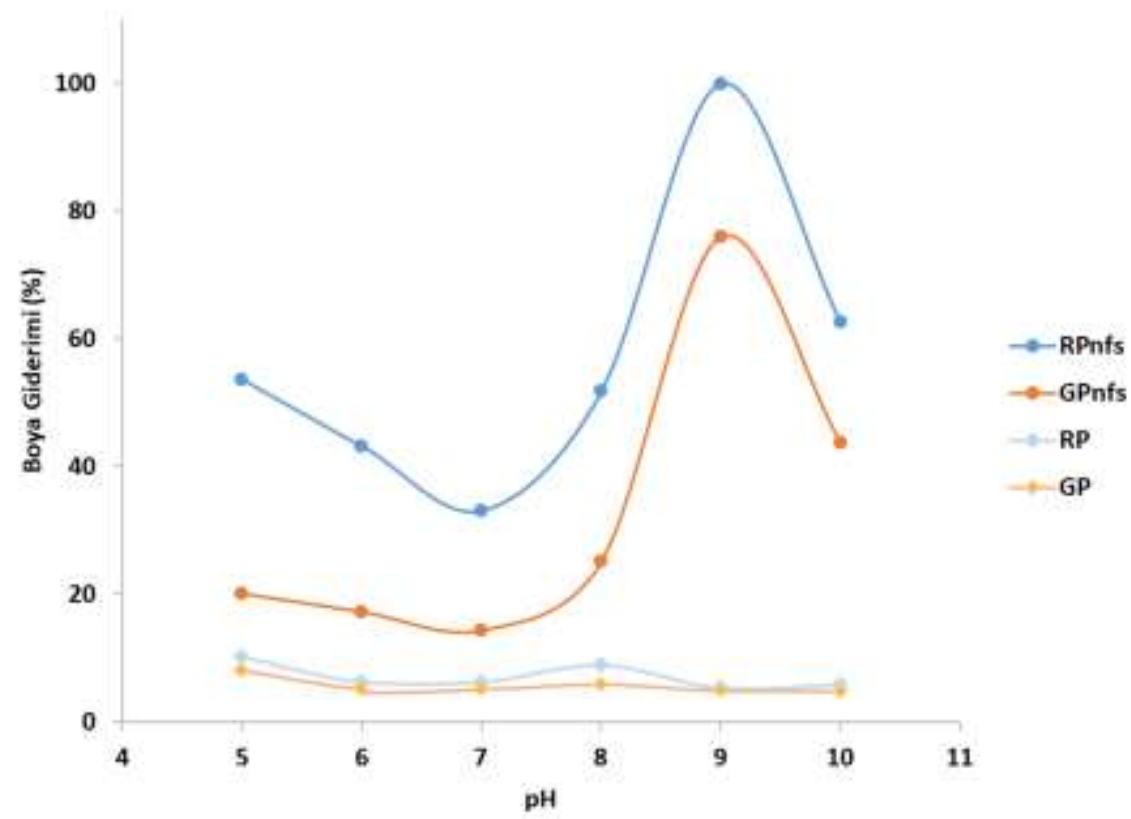

Şekil 6. Direct blue 1 boya giderimine $\mathrm{pH}$ nın etkisi $\left(50\right.$. dakika, $25^{\circ} \mathrm{C}$ )

\subsection{Direct blue 1 enzimatik boya giderimine sıcaklığın etkisi}

Optimum $\mathrm{pH}$ tespit edildikten sonra optimum reaksiyon sıcaklığının belirlenmesi için üç farklı sıcaklık test edildi. Şekil 7'de görüldüğü üzere oda sıcaklığında gerçekleştirilen boya gideriminde GPnfs yapısı 50. dakikada $\% 76$ oranında boya giderirken sıcaklık yükseltildiğinde giderim azalmış sırasıyla \%69 $\left(40^{\circ} \mathrm{C}\right)$ ve $\% 56\left(60^{\circ} \mathrm{C}\right)$ 'ya düşmüştür. RPnfs yapısı ise aynı koşullarda 50 . dakikada $\% 100$ oranında boya giderirken sıcaklık yükseltildiğinde giderim azalmış sırasıyla $\% 90\left(40^{\circ} \mathrm{C}\right)$ ve $\% 70\left(60^{\circ} \mathrm{C}\right)$ 'e düşmüştür. $\mathrm{Bu}$ nedenle çalışmamızda optimum boya giderimi sıcaklığı oda sıcaklığ 1 kabul edilen $25^{\circ} \mathrm{C}$ olarak belirlenmiştir. Literatürde ise $M$.charantia meyvesinden peroksidaz enzimi saflaştırılarak bu çalışmadan farklı bir yöntem ile immobilize edilmiş olup 50-200 mg/L konsantrasyon aralığında değişen Reactive blue 4-160-171, Reactive orange 4-86,reactive red 120 ve recative yellow 84 gibi farklı türde boyaların giderimi için optimum çalışma sıcaklığ $40^{\circ} \mathrm{C}$ olarak belirlenmiştir [28]. 


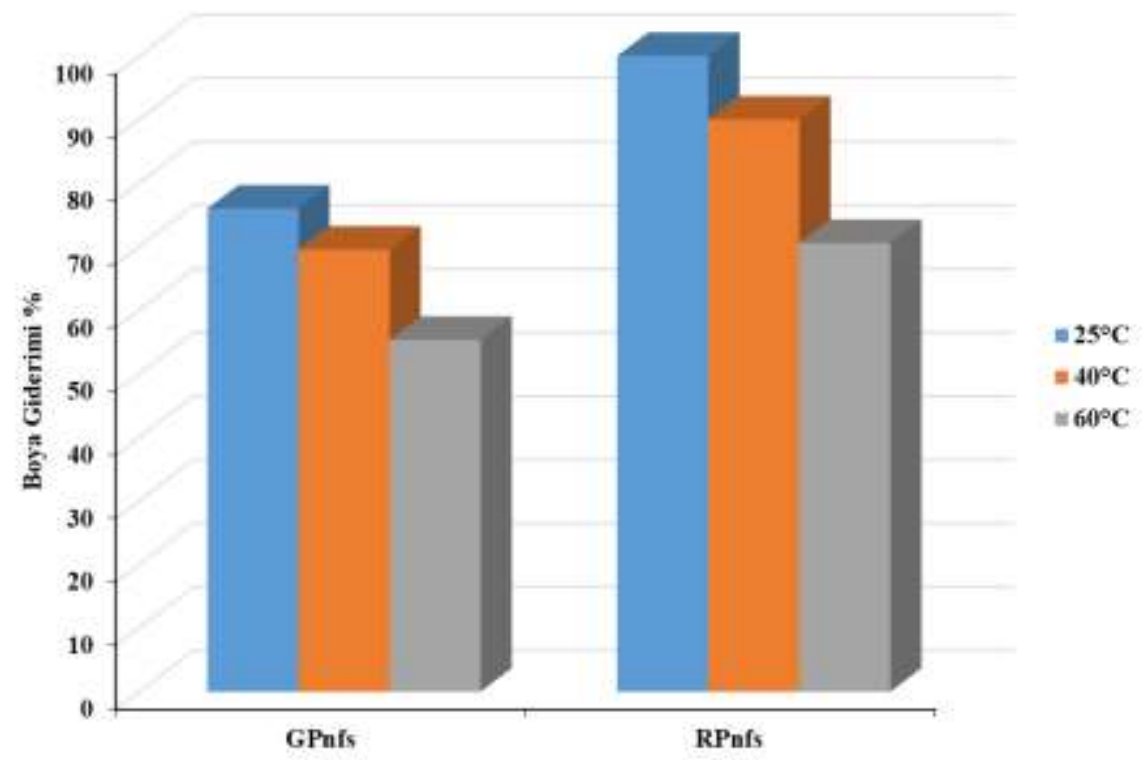

Şekil 7. Direct blue 1 boya giderimine sıcaklığın etkisi (pH 9, 50. dakika)

\subsection{Direct blue 1 boya gideriminde hibrit nano çiçeklerin tekrar kullanılabilirliği}

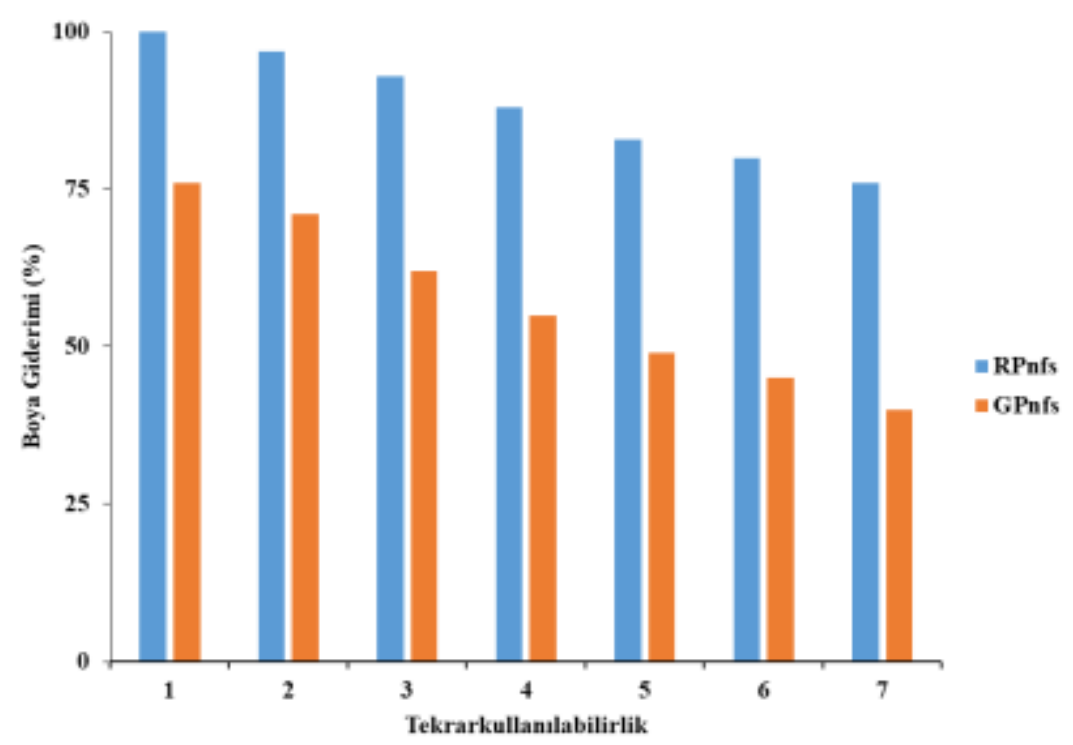

Şekil 8. Direct blue 1 boya giderimine hibrit nano çiçeklerin tekrar kullanılabilirliği $\left(50\right.$. dakika, $\left.25^{\circ} \mathrm{C}\right)$

Şekil 8'de gösterildiği üzere RPnfs hibrit nano çiçek yapısı 7. kez kullanımda dahi başlangıçta gösterdiği aktivitenin \%76' sını korumaktadır. GPnfs hibrit nano çiçek yapısı ise 7. kez kullanımda başlangıçta gösterdiği aktivitenin \%53'ünü korumaktadır. Benzer şekilde literatürde yapılan diğer bir çalışmada immobilize kudret narı peroksidazı 10 . kez kullanımda başlangıçta gösterdiği aktivitenin yaklaşık \%50'sini korumaktadır [28].

\section{Sonuç ve Öneriler}

$\mathrm{Bu}$ çalışmada ham ve olgunlaşmış kudret narı meyvesinden peroksidaz enzimi saflaştırması için optimum koşullar tespit edilmiş olup farklı büyüme safhalarında yer alan meyvenin peroksidaz aktiviteleri karşılaştırmalı olarak araştırılmıştır. Doğal ve ucuz bir kaynaktan yüksek verimle saflaştırılmış peroksidaz enzimleri kullanılarak hibrit nano çiçek yapıları sentezlenmiş olup yapının yapısal ve morfolojik özellikleri gözlenmiştir. 
Sonuç olarak ham ve olgun meyve değerlendirildiğinde ham meyvenin toplam protein içeriği olgun meyveye göre daha yüksek bulunurken olgun meyveden yapılan enzim saflaştırması ham meyveden yapılan enzim saflaştırmasına göre daha yüksek peroksidaz enzim aktivitesi göstermiştir. Saflaştırılan serbest formdaki peroksidaz enzimleri hibrit nano çiçek sentez yöntemi ile immobilize edildiğinde serbest formlarına göre daha yüksek enzimatik aktivite sergilemişlerdir. Ve en yüksek peroksidaz aktivitesi olgun meyvede ve hibrit nano çiçek formunda görülmüştür. Boya giderim sonuçları ise hibrit nano çiçek yapıların boya gideriminde etkin şekilde kullanılabildiğini göstermiştir. Özellikle ham meyve peroksidazı kullanılarak sentezlenen hibrit nano çiçek formu daha fazla fenolik madde giderimi yapmaktadır.

\section{Teşekkür}

Ham ve olgunlaşmış kudret narı (M. charantia) temini için Erciyes Üniversitesi Seyrani Ziraat Fakültesi Öğretim Üyesi Prof. Dr. Halit YETişiR'e teşekkür ederiz.

\section{Yazarların Katkısı}

Tüm yazarlar makale için hipotez oluşturulmasına ve verilerin işlenmesine eşit oranda katkı sağlamıştır. Bununla birlikte Dr. Öğr. Üyesi Ayşe BALDEMİR KILIÇ kudret narı temini ve hazırlanması aşamasında, Dr. Öğr. Üyesi Cevahir ALTINKAYNAK ise deneylerin yapılması, verilerin yorumlanması ve makalenin yazımında ayrıca katkı sağlamıştır.

\section{Çıkar Çatışması Beyanı}

Yazarlar arasında herhangi bir çıkar çatışması bulunmamaktadır.

\section{Araştırma ve Yayın Etiği Beyanı}

Yapılan çalışmada, araştırma ve yayın etiğine uyulmuştur. Bu çalışmada etik kurul izni gerekmemektedir.

\section{Kaynaklar}

[1] Husain Q., Jan U. 2000. Detoxification of phenols and aromatic amines from polluted wastewater by using phenol oxidases. J Sci Ind Res., 59: 286-293.

[2] Duran N., Esposito E. 2000. Potential applications of oxidative enzymes and phenoloxidase-like compounds in wastewater and soil treatment: a review. Appl Catal B: Environ., 28: 83-99.

[3] Torres E., Bustos-Jaimes I., Le Bogne S. 2003. Potential use of oxidative enzymes for the detoxification of organic pollutants. Appl. Catal. B: Environ., 46: 1-15.

[4] Oller I., Malato S., Sánchez-Pérez J. 2011. Combination of advanced oxidation processes and biological treatments for wastewater decontamination-a review. Science of the total environment, 409 (20): 4141-4166.

[5] Ahmed S., Rasul M.G., Brown R., Hashib M.A. 2011. Influence of parameters on the heterogeneous photocatalytic degradation of pesticides and phenolic contaminants in wastewater: a short review. Journal of Environmental Management, 92 (3): 311-330.

[6] Bhunia A, Durani S., Wangikar P.P. 2001. Horseradish peroxidase catalyzed degradation of industrially important dyes. Biotechnol. Bioeng., 72: 562-567.

[7] Bilal M., Iqbal H.M., Shah S.H., Hu H., Wang W., Zhang X. 2016. Horseradish peroxidaseassisted approach to decolorize and detoxify dye pollutants in a packed bed bioreactor. Journal of Environmental Management, 183: 836-842.

[8] Altinkaynak C., Tavlasoglu S., Kalin R., Sadegihan N., Özdemir H., Ocsoy I., Özdemir N. 2017. A Hierarchical Assembly of Flower-Like Hybrid Turkish Black Radish Peroxidase-Cu ${ }^{2+}$ Nanobiocatalyst and Its Effective Use in Dye Decolorization. Chemosphere, 182: 122-128.

[9] Sassolas A., Blum L.J., Leca-Bouvier B.D. 2012. Immobilization strategies to develop enzymatic biosensors. Biotechnology Advances, 30: 489-511. 
[10] Kim J., Grate J.W., Wang P. 2006. Nanostructures for Enzyme Stabilization. Chemical Engineering Science, 61: 1017-1026.

[11] Altinkaynak C., Tavlasoglu S., Özdemir N., Ocsoy I. 2016. A new generation approach in enzyme immobilization: Organic-inorganic hybrid nanoflowers with enhanced catalytic activity and stability. Enzyme Microb Technol., 93-94:105-112.

[12] Ge J., Lei J., Zare R.N. 2012. Protein-inorganic hybrid nanoflowers. Nature Nanotechnology, 428-432.

[13] Altinkaynak C., Kocazorbaz E., Özdemir N., Zihnioglu F. 2018. Egg White Hybrid Nanoflower (EW-Hnf) With Biomimetic Polyphenol Oxidase Reactivity: Synthesis, Characterization and Potential Use in Decolorization of Synthetic Dyes. Int. J. Biol. Macromol., 109: 205-211.

[14] Zhu X., Huang J., Liu J., Zhang H., Jiang J., Yu R. 2017. A dual enzyme-inorganic hybrid nanoflower incorporated microfluidic paper-based analytic device ( $\mu \mathrm{PAD})$ biosensor for sensitive visualized detection of glucose. Nanoscale, 9: 5658-5663.

[15] Jiao J., Xin X., Wang X., Xie Z., Xia C., Pan W. 2017. Self-assembly of biosurfactant-inorganic hybrid nanoflowers as efficient catalysts for degradation of cationic dyes. RSC Adv., 7: 4347443482.

[16] Gulmez C., Altinkaynak C., Özdemir N., Atakisi O. 2018. Proteinase K hybrid nanoflowers (P$\mathrm{hNFs}$ ) as a novel nanobiocatalytic detergent additive. International Journal of Biological Macromolecules, 119: 803-810.

[17] Jun C., Shao M.Y., Peng Z. 2006. Horseradish peroxidase immobilized on aluminum-pillared interlayered clay for the catalytic oxidation of phenolic wastewater. Water Research, 40: 283-290.

[18] Somtürk B., Kalın R., Özdemir N. 2014. Purification of peroxidase from red cabbage (Brassica oleracea var. capitata $f$. rubra) by affinity chromatography. Applied Biochemistry Biotechnology, 173: 1815-1828.

[19] ShaffIqu T.S., Roy J.J., Nair R.A., Abraham T.E. 2002. Degradation of textile dyes mediated by plant peroxidases. Applied Biochemistry and Biotechnology, 102-103: 315-326.

[20] Baldemir A., Ekinci K., İlgün S., Dalda A., Yetişir, H. 2018. Momordica charantia L. (kudret narı) meyvelerinin toplam fenolik madde içerikleri ve antioksidan kapasitelerinin değerlendirilmesi. Derim, 35 (1): 45-50.

[21] Nagarani G., Abirami A., Siddhuraju P. 2014. A comparative study on antioxidant potentials, inhibitory activities against key enzymes related to metabolic syndrome, and antiinflammatoryactivity of leaf extract from different Momordica species. Food Science and Human Wellness, 3: 36-46.

[22] Akhtar S., Ali Khan A., Husain, Q. 2005. Simultaneous purification and immobilization of bitter gourd (Momordica charantia) peroxidases on bioaffinity support. Journal of chemical technology and biotechnology, 80 (2): 198-205.

[23] Panadare Dhanashree C., Rathod Virendra K. 2017. Extraction of peroxidase from bitter gourd (Momordica charantia) by three phase partitioning with dimethyl carbonate (DMC) as organic phase. Process biochemistry, 61: 195-201.

[24] Altinkaynak C., Yilmaz I., Koksal Z., Özdemir H., Ocsoy I., Özdemir N. 2016. Preparation of lactoperoxidase incorporated hybrid nanoflower and its excellent activity and stability. Int. J. Biol. Macromolec., 84: 402-409.

[25] Altinkaynak C., Tavlasoglu S., Özdemir N., Ocsoy I. 2016. A new generation approach in enzyme immobilization: organic-inorganic hybrid nanoflowers with enhanced catalytic activity and stability. Enzyme Microb. Technol., 93-94: 105-112.

[26] Zian L., Yun X., Yin Y., Hu W., Liu W., Yang H. 2014. Facile synthesis of Enzyme-inorganic hybrid nanoflowers and its application as colorimetric platform for visual detection of hydrogen perosixde and phenol. ACS Applied Materials \& Interfaces, 6: 10775-10782.

[27] Akhtar S., Ali Khan A., Husain Q. 2005. Partially purified bitter gourd (Momordica charantia) peroxidase catalyzed decolorization of textile and other industrially important dyes. Bioresour Technol., 96 (16): 1804-1811.

[28] Akhtar S., Khan A.A., Husain Q. 2005. Potential of immobilized bitter gourd (Momordica charantia) peroxidase in tge decolorization and removal of textile dyes from polluted wastewater and dyeing effluent. Chemosphere, 60: 291-301. 